\title{
Sediment supply from lateral moraines to a debris-covered glacier in the Himalaya
}

\author{
Teun van Woerkom ${ }^{1}$, Jakob F. Steiner ${ }^{1}$, Philip D. A. Kraaijenbrink ${ }^{1}$, Evan S. Miles ${ }^{2}$, and \\ Walter W. Immerzeel ${ }^{1}$ \\ ${ }^{1}$ Utrecht University, Department of Physical Geography, P.O. Box 80115, Utrecht, the Netherlands \\ ${ }^{2}$ School of Geography, University of Leeds, Leeds, UK \\ Correspondence: Teun van Woerkom (t.a.a.vanwoerkom@uu.nl)
}

Received: 2 August 2018 - Discussion started: 11 September 201

Revised: 30 January 2019 - Accepted: 25 April 2019 - Published: 14 May 2019

\begin{abstract}
Debris-covered glaciers in the Himalaya play an important role in the high-altitude water cycle. The thickness of the debris layer is a key control of the melt rate of those glaciers, yet little is known about the relative importance of the three potential sources of debris supply: the rockwalls, the glacier bed and the lateral moraines. In this study, we hypothesize that mass movement from the lateral moraines is a significant debris supply to debris-covered glaciers, in particular when the glacier is disconnected from the rockwall due to downwasting. To test this hypothesis, eight high-resolution and accurate digital elevation models from the lateral moraines of the debris-covered Lirung Glacier in Nepal are used. These are created using structure from motion (SfM), based on images captured using an unmanned aerial vehicle between May 2013 and April 2018. The analysis shows that mass transport results in an elevation change on the lateral moraines with an average rate of $-0.31 \pm 0.26 \mathrm{~m} \mathrm{year}^{-1}$ during this period, partly related to sub-moraine ice melt. There is a higher elevation change rate observed in the monsoon $\left(-0.39 \pm 0.74 \mathrm{~m} \mathrm{year}^{-1}\right)$ than in the dry season $\left(-0.23 \pm 0.68 \mathrm{~m}_{\text {year }}{ }^{-1}\right)$. The lower debris aprons of the lateral moraines decrease in elevation at a faster rate during both seasons, probably due to the melt of ice below. The surface lowering rates of the upper gullied moraine, with no ice core below, translate into an annual increase in debris thickness of $0.08 \mathrm{~m} \mathrm{year}^{-1}$ along a narrow margin of the glacier surface, with an observed absolute thickness of approximately $1 \mathrm{~m}$, reducing melt rates of underlying glacier ice. Further research should focus on how large this negative feedback is in controlling melt and how debris is redistributed on the glacier surface.
\end{abstract}

\section{Introduction}

Glaciers cover approximately $110000 \mathrm{~km}^{2}$ in high-mountain Asia (HMA) and as such constitute an important water storage of the region (Pfeffer et al., 2014; Immerzeel et al., 2010). The glaciers are likely to melt rapidly in the future, with projections ranging from a total mass loss of $36 \%$ to $64 \%$ in the coming century depending on the climate scenario (Kraaijenbrink et al., 2017). While the entire HMA has experienced an overall glacier mass and area loss in recent decades, the changes have been found to be variable in space (Bolch et al., 2012; Kääb et al., 2012; Brun et al., 2017). Apart from differences in climate, the presence of debris with variable thickness on the glacier tongues plays an important role to explain this spatial heterogeneity (Scherler et al., 2011; Gardelle et al., 2012; Kääb et al., 2012).

Although the debris-covered area only constitutes $11 \%$ of the total glacier area, $30 \%$ of the ice mass below the equilibrium line altitude (ELA) is covered with debris (Kraaijenbrink et al., 2017). While a thin debris cover increases melt because it decreases albedo, debris thickness above a critical thickness inhibits melt (Östrem, 1959). The surface of a debris-covered glacier is often characterized by ice cliffs and supraglacial ponds, which result in high local melt rates (Immerzeel et al., 2014b; Steiner et al., 2015; Thompson et al., 2016; Miles et al., 2017a). Knowledge about actual debris thickness is limited to few field obser- 
vations (Nicholson and Benn, 2006; Ragettli et al., 2015; McCarthy et al., 2017) and attempts to derive it from thermal bands of satellite imagery (Mihalcea et al., 2008; Pfeffer et al., 2014; Rounce and McKinney, 2014; Schauwecker et al., 2015; Rounce et al., 2018). Several studies suggest that glaciers with prolonged periods of negative mass balance are associated with an increase in debris cover (Deline, 2005; Mihalcea et al., 2006; Stokes et al., 2007; Shukla et al., 2009; Kirkbride and Deline, 2013; Gibson et al., 2017a). Glaciers that have a neutral or positive mass balance, such as in the Karakoram in Pakistan, do not show any positive trends in debris-covered area (Herreid et al., 2015).

Not only is the debris-covered area variable, but the thickness also changes over time. A recent study on the Baltoro Glacier in Pakistan suggested that debris thickness changes at rates of multiple centimetres per year with a maximum of $30 \mathrm{~cm}$ year $^{-1}$ near the snout (Gibson et al., 2017a).

The source of supraglacial debris has been studied for decades (Reheis, 1975; Boulton, 1978). Three potential sources of supraglacial debris can be distinguished, which can be divided into direct and indirect sources. The direct sources are basal erosion and bordering rockwalls. The indirect source is the lateral moraine, from which temporarily deposited debris is remobilized and transported (Fig. 1A). The relative contribution of these sources is variable but generally depends on the amount and intensity of precipitation, glacier size, rockwall extent and erodibility of the bedrock and sediments (Benn and Ballantyne, 1994; Benn and Owen, 2002). In HMA, basal erosion (Fig. 1Aa) is likely only of limited relative importance, as the erosion processes on the steep rockwalls and lateral moraines are highly active (Benn and Ballantyne, 1994; Benn and Owen, 2002). Bordering rockwalls have been observed to transport debris to the glacier via rockfall, rock avalanches and landslides as primary transporting processes (Fig. 1Ab). These periodic events can be triggered by processes such as extreme rainfall or seismic events, and are known to increase due to glacier melt and downwasting of the surface resulting in debuttressing and exposure of unsupported strata (Soldati et al., 2004; Deline et al., 2014).

Generally, long-term rockwall erosion rates are on the order of $1 \mathrm{~mm}$ year $^{-1}$ (Heimsath and McGlynn, 2008). However, the actual mass deposited on the glacier surface is more difficult to determine and varies from glacier to glacier, depending on its exposure to rockwalls and geologic conditions. The reworking of these deposits on the glacier surface, as a result of local hillslope geomorphology, surface melt, glacier flow and englacial processes, may lead to small-scale variations in debris cover as found in the Himalaya. In contrast to transport from the rockwalls, which deposits material on specific locations, remobilization of lateral moraine debris can result in a much more spatially uniform debris supply to the glacier (Fig. 1Ac). Lateral moraines typically have a gullied upper part, where debris flows are the main transport process (Curry et al., 2006) (Fig. 1Bc1). Most of these flows are released due to rainfall saturation, but the melt of buried ice cores can contribute as well (Ballantyne, 2013). The oversteepened upper parts may also be susceptible to rockfall (Lukas et al., 2012) (Fig. 1Bc2). Eroded gully material is deposited near the glacier margin as coalescing debris cones, which, together with rockfall and slumping, forms the lower debris apron of the moraine. The material on these debris aprons is reworked by frost action, small landslides, debris flows, snow avalanches and solifluction (Fig. 1Bc3).

During downwasting, the glacier surface becomes lower than the moraine crest, making lateral moraine slopes susceptible to mass transport processes. As more and more of the moraine slopes become exposed, a larger amount of moraine debris can be transported to the glacier surface and their relative contribution to the sediment budget will increase. This is particularly the case for stagnating glacier tongues, where the distal slope of the lateral moraine has the opposite aspect of the adjacent valley slopes (Fig. 3). Due to glacier retreat and downwasting, the valley wall is disconnected from the actual tongue. Material deposited below the ELA will furthermore remain at the glacier surface and add to the supraglacial debris cover. Estimated rates of vertical lowering on the lateral moraines range from 49 to $151 \mathrm{~mm}_{\text {year }}{ }^{-1}$ for the European Alps (Curry et al., 2006) and 3 to $169 \mathrm{~mm} \mathrm{year}^{-1}$ for Norwegian field sites (Curry et al., 2006). On glaciers in the study area (Langtang Valley in Nepal), a supply rate of 0.4$31 \mathrm{~mm}$ year $^{-1}$ (Watanabe et al., 1998) was previously found. However, these values are averages over a much longer time span $(<550$ years versus $<247$ years for studies in Norway and $<79$ for the Alps; Curry et al., 2006) or include source areas beyond the moraines (Watanabe et al., 1998). These rates are nonetheless all much higher than rockwall erosion rates. All eroded material is deposited on debris cones (often on top of the glacier ice), which are intensely reworked throughout the study period.

Previous studies only reported glacier-averaged erosion rates, although it is likely that the rates are spatially variable. We hypothesize that transport of remobilized debris from lateral moraines can explain the thick and continuous debris cover of tongues on downwasting debris-covered glaciers that have been disconnected from headwalls, in HMA. To this end, we use multi-annual, high-resolution orthomosaics and digital elevation models (DEMs) acquired using an unmanned aerial vehicle (UAV) to quantify surface lowering rates of the lateral moraines of a debris-covered glacier in Nepal. We attempt to explain the spatiotemporal variability and sediment transport processes using the terrain morphology and prevailing seasonal climates. Finally, we assess how important erosion from lateral moraines is in the formation of Himalayan debris-covered glaciers.

\section{Study area}

The research was conducted on Lirung Glacier $\left(28.23^{\circ} \mathrm{N}\right.$, $85.56^{\circ} \mathrm{E}$ ), which is located in the Langtang Valley in the 

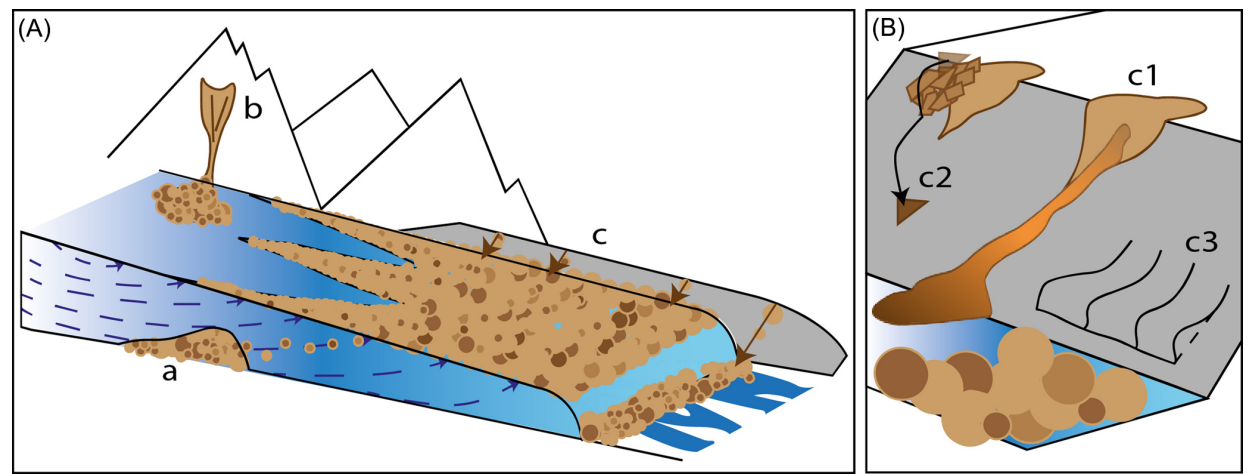

Figure 1. Schematization of debris supply processes towards the glacier surface (A), showing basal erosion (a), rockwall erosion (b) and sediment supply from lateral moraines (c). Mass transport processes on a lateral moraine bordering the glacier (B), showing debris flows (c1), rockfall (c2) and slow slumping (partly caused by the melt of sub-moraine ice) (c3).

Nepalese Himalaya (Fig. 2b). The glacier has a southern aspect, steep rockwalls near the mountain crest and an almost flat terminus. The lower part of the glacier is covered entirely in debris (Fig. 4) and has been subject to strong downwasting in recent decades (Immerzeel et al., 2014a; Nuimura et al., 2017). The study area is located between 3900 and $4400 \mathrm{~m}$ a.m.s.l. (Fig. 2c, orange lines). In this section, debris from the valley rockwall cannot reach the glacier surface due to the opposite aspect of the distal moraine slopes (Fig. 3). The climate in the region is dominated by the monsoon, with a wet season between June and September in which $70 \%$ of the annual precipitation falls. During the dry season between November and May, considerably less precipitation reaches the area and falls mostly as snow (Immerzeel et al., 2014b).

\section{Data and methods}

\subsection{Field data}

Our observations of the lateral moraines of Lirung Glacier span 2013 to 2018, consisting of images captured during multiple UAV flights with an optical camera. A structure from motion (SfM) workflow (Lucieer et al., 2014) is used to derive three-dimensional (3-D) point clouds, which are georeferenced by marking measured ground control points (GCPs) and tie points. These operations finally result in coregistered orthomosaics $(0.1 \mathrm{~m}$ resolution) and DEMs $(0.2 \mathrm{~m}$ resolution; for further details regarding measurements, processing and data quality, see Kraaijenbrink et al., 2016). Details about the mapped part of the glacier for each UAV campaign are provided in Table 1 . The mutually overlapping area of all datasets covers $1.5 \mathrm{~km}^{2}$ of the glacier tongue including the moraines. The accuracy of all generated DEMs is tested by comparing the differences between DEM and GCPs.
Table 1. Date of acquisition (in yyyy/mm/dd format) and area of the different datasets.

\begin{tabular}{lr}
\hline Date & $\begin{array}{r}\text { Mapped area } \\
\left(\mathrm{km}^{2}\right)\end{array}$ \\
\hline $2013 / 05 / 18$ & 2.04 \\
$2013 / 10 / 22$ & 3.25 \\
$2015 / 10 / 18$ & 2.61 \\
$2016 / 04 / 30$ & 1.97 \\
$2016 / 10 / 06$ & 2.70 \\
$2017 / 04 / 20$ & 1.41 \\
$2017 / 10 / 19$ & 2.32 \\
$2018 / 04 / 28$ & 2.12 \\
\hline
\end{tabular}

Precipitation data were available from the meteorological station at Kyanjing Village $\left(28.21^{\circ} \mathrm{N}, 85.57^{\circ} \mathrm{E}\right)$ about $1.3 \mathrm{~km}$ south of the glacier in 2013. As data gaps are present between 2015 and 2018 for the Kyanjing station, the meteorological station in Langshisha $\left(28.20^{\circ} \mathrm{N}, 85.67^{\circ} \mathrm{E}\right)$ about $13 \mathrm{~km}$ south-east of the glacier was used for the remainder of the period. Both rainfall intensities and the cumulative rainfall between any two UAV time slices were analysed.

\subsection{Deriving change in elevation}

The DEMs were used to calculate vertical elevation differences between time steps. Two preprocessing steps were taken. First, vegetated areas were selected using a maximum likelihood supervised classification applied to the orthomosaic and masked out of the DEMs, to remove noise related to vegetation growth and decay. Second, as the off-glacier and off-moraine terrain did not show signs of sediment transport during the investigated time span, these areas are assumed to be stable. Therefore, the DEMs were corrected for elevation changes in off-moraine and off-glacier terrain. To avoid bias towards possible errors in the DEM, we removed the outliers outside the 10-90th percentile range, while making sure to 

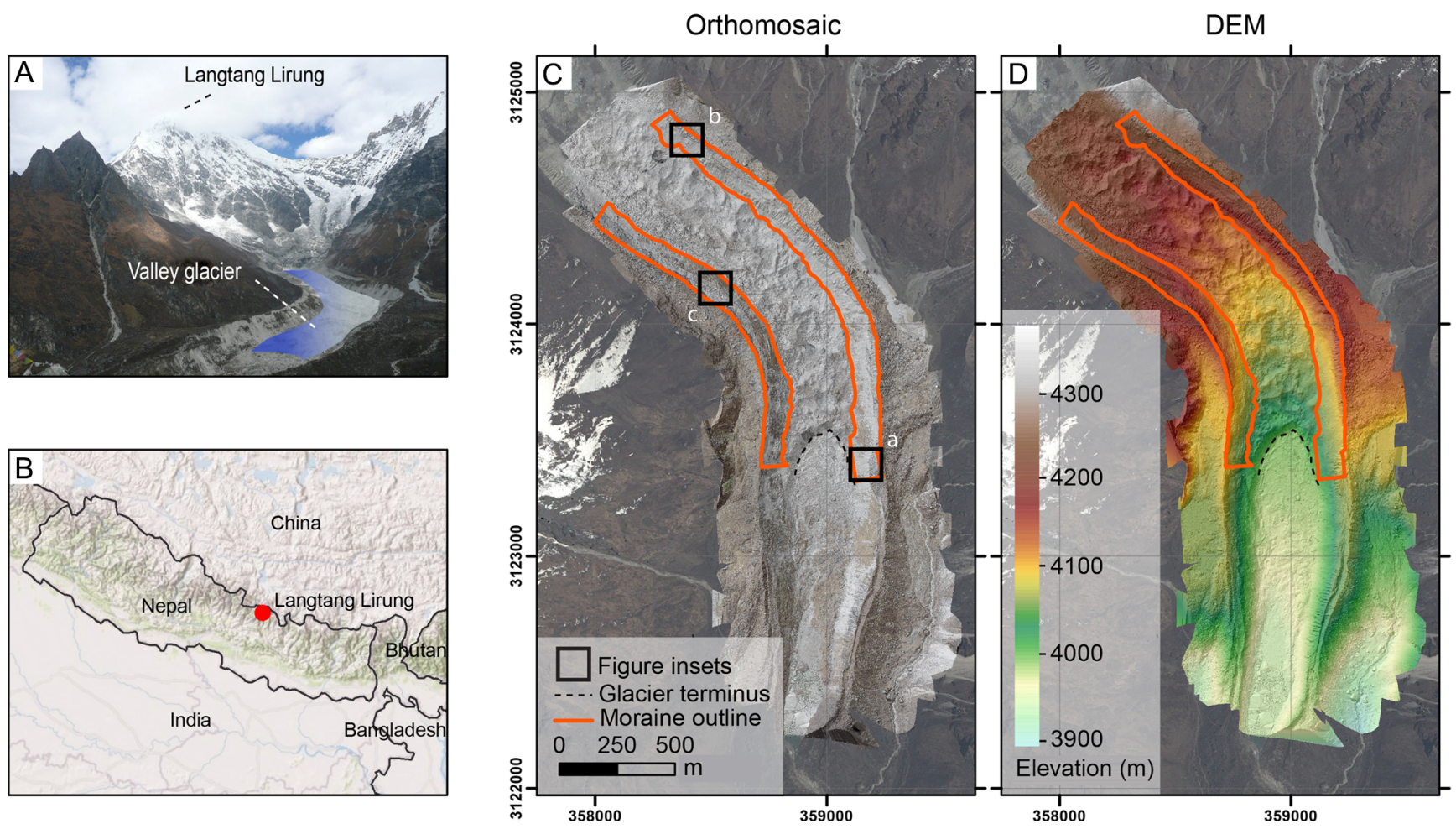

Figure 2. Study area including the setting (A), location of the study area (B) and two more detailed overviews including the orthomosaic and elevation data of the study area (C, D; from UAV flights in October 2015). The glacier terminus and studied section of the moraine are outlined on these maps. The black squares in panel (C) indicate the location of Figs. 5 (a), $6 \mathrm{a}(\mathbf{b})$ and b (c).

Table 2. Extreme values below and above which the data are removed from the original dataset, as well as the mean of the whole dataset $(\mu)$.

\begin{tabular}{lrrr}
\hline Dataset (yyyy/mm) & $\begin{array}{r}\mu \\
(\mathrm{m})\end{array}$ & $\begin{array}{r}\text { 10th percentile } \\
(\mathrm{m})\end{array}$ & $\begin{array}{r}\text { 90th percentile } \\
(\mathrm{m})\end{array}$ \\
\hline $2013 / 05-2013 / 10$ (wet) & -0.39 & -2.07 & 1.18 \\
$2015 / 10-2016 / 04$ (dry) & -0.17 & -1.06 & 0.72 \\
$2016 / 04-2016 / 10$ (wet) & -0.34 & -1.47 & 0.87 \\
$2016 / 10-2017 / 04$ (dry) & -0.36 & -1.11 & 0.37 \\
$2017 / 04-2017 / 10$ (wet) & -0.52 & -2.16 & 1.11 \\
$2017 / 10-2018 / 04$ (dry) & -0.22 & -0.88 & 0.13 \\
$2013 / 05-2018 / 04$ (total) & -0.31 & -0.31 & 0.79 \\
\hline
\end{tabular}

retain large elevation change events related to debris flows and rockfall (Table 2). Finally, the glacial elevation change over the entire period (2018-2013) is determined for a $20 \mathrm{~m}$ wide zone next to the proximal slope of the moraine, which is an indication of the glacial melt underneath the debris apron. When taking these corrections into account, the difference in elevation between two time steps was assumed equal to the amount of sediment transport.

\subsection{Analysis of surface properties}

The orthomosaics were analysed visually to examine patterns of erosion and deposition, and compared against elevation differences. Furthermore, the displacement, slope and roughness of the lateral moraines were derived from the DEMs. We employed the COSI-Corr software for cross-correlation feature tracking to calculate the displacement of debris on the lateral moraines (Leprince et al., 2007; Kraaijenbrink et al., 2016). As this software focuses more on block movement than on individual clast displacement (Leprince et al., 2007), correlating displacement with elevation change gives insight in slower slope processes such as creep or slow slumping, which often occur on a scale large enough to be detected by COSI-Corr. Fast events that travel beyond our chosen maximum window size of $26.5 \mathrm{~m}$ are registered by the algorithm as noise and hence do not bias our average velocities on the moraine. Slope maps are created directly from the DEM. Following Nield et al. (2013), the roughness length $z_{0}(\mathrm{~m})$ was derived by

$\ln \left(z_{0}\right)=0.65+1.37 \ln \left(\sigma_{z}\right)$,

with $\sigma_{z}$ defined as the standard deviation of a $5 \times 5 \mathrm{~m}$ window of a detrended DEM. Although the window size greatly influences the roughness, a window of $25 \mathrm{~m}^{2}$ is suitable for this approach (Miles et al., 2017b). For each window, a high 

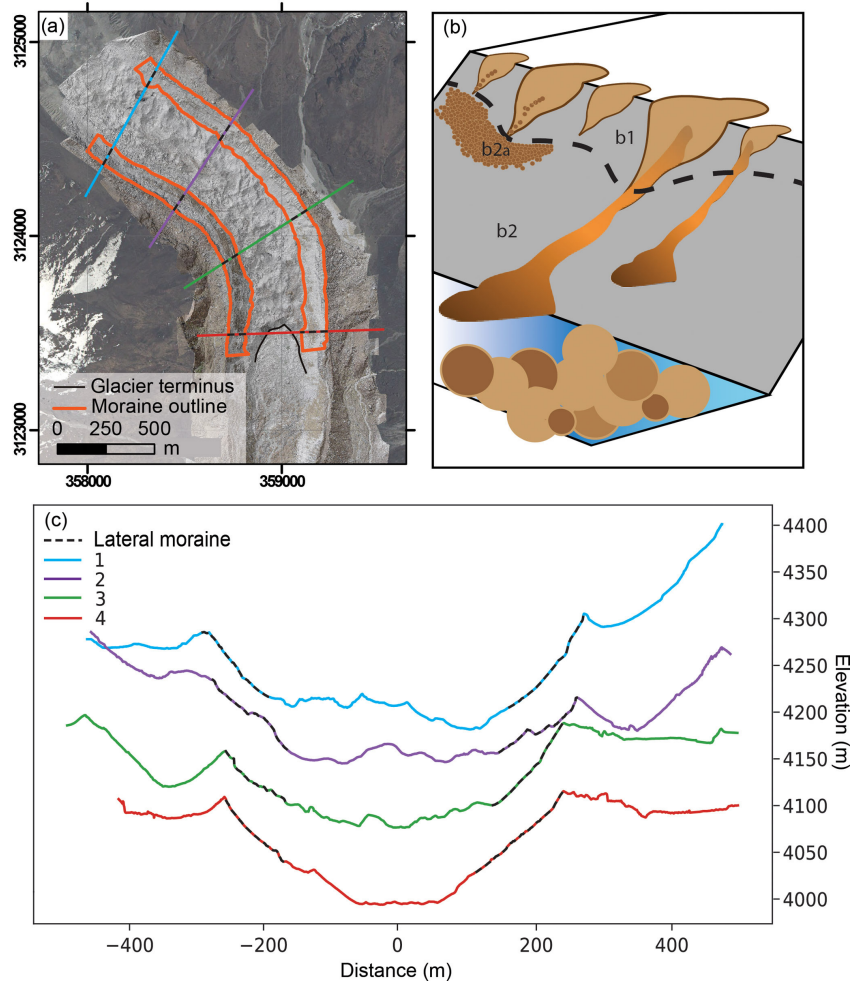

Figure 3. Cross sections over the glacier and moraine, with their locations (a) and corresponding elevation profile (c). They clearly indicate that the distal slope of the moraine has an opposite aspect to the proximal slope, due to which there is no debris input from higher slopes and rockwalls in the valley. In panel (b), the different sections of the moraine are indicated, with the upper gullied part (b1), the debris apron or coalescing debris cones (b2) and the smooth section of the debris apron interpreted as gully washout deposition (b2a).

roughness value indicates larger topographic variation, such as boulders, while a small value indicates a more homogeneous surface (Miles et al., 2017b).

\subsection{Moraine delineation}

The DEM and orthomosaic, as well as their derivatives, were used to delineate the lateral moraines and divide them into zones with comparable characteristics. The moraine base is often characterized by a break in slope (Figs. 4, 5b). Furthermore, a hillshade with a hummocky appearance is an indicator for sub-debris ice (Lukas et al., 2012), and these areas are thus excluded from the moraine. Within the lateral moraine two main zones were distinguished: an intensively gullied upper part (Curry et al., 2006) and a lower part that consists mainly of reworked debris, usually in the form of coalescing debris cones (Figs. 2, 4, 5a), as also described by Ballantyne (2013). Although not distinguishable everywhere, a zone with fine material was detected directly below the gullied upper part, accompanied by a very low roughness (Figs. 3b, 5c). The smoothness is also visible on the ortho-

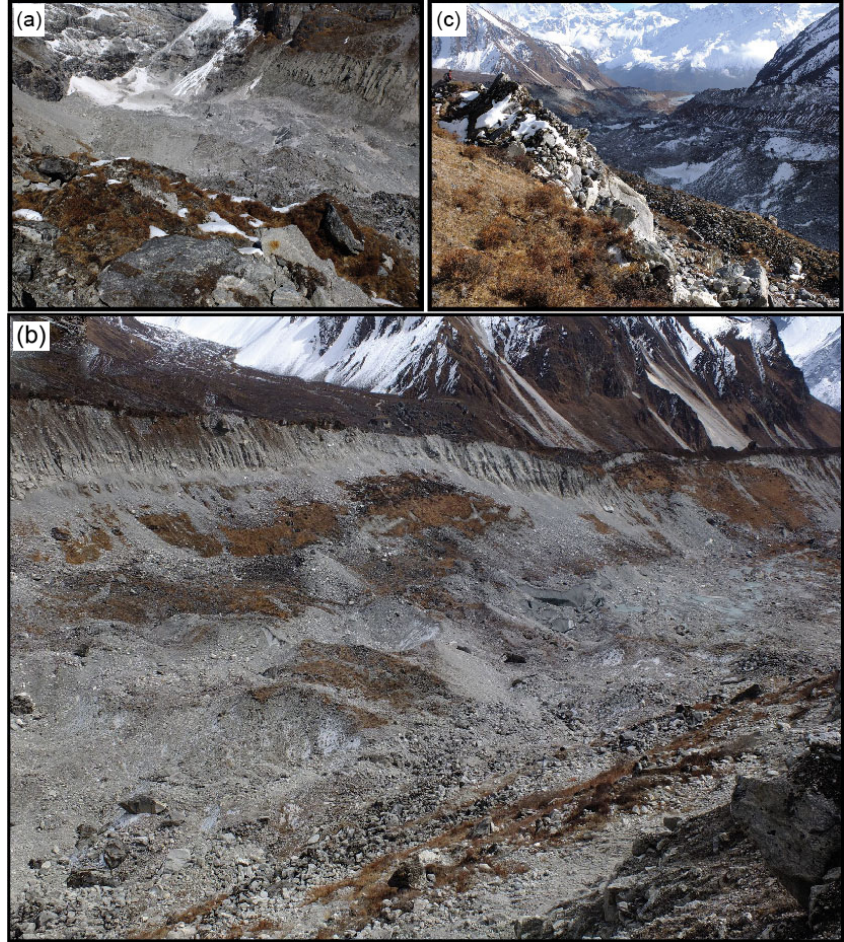

Figure 4. Field images of Lirung Glacier from the upper part (a), where the rockwalls are still connected to the glacier, along the middle disconnected part (b) to the lower glacier tongue (c), where the decoupling is clearly visible. Also note the mass movements from the upper slopes (b) that do not reach the glacier.

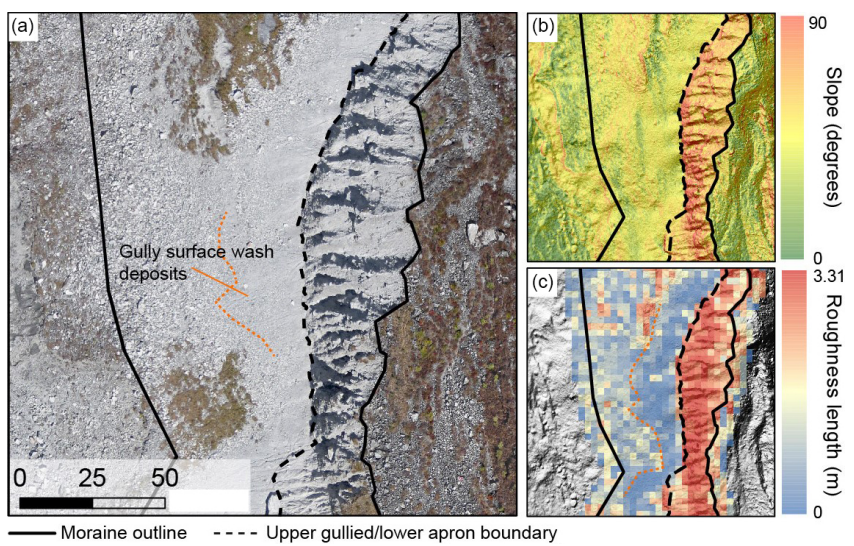

Figure 5. Moraine delineation method. The crest is often well defined by the orthomosaic (a) and slope (b). An intermediate zone with gully surface wash deposition is clearly visible from the roughness data (c). The moraine consists of an intensely gullied upper part (right) and a lower debris apron consisting of coalescing debris cones (left). See Fig. 2 for location.

mosaic. We interpret this part of the coalescing cones as the deposition zone of surface wash from the gullies upslope. 


\subsection{Runout model}

To investigate the importance of the lateral moraines as a source for supraglacial debris, we used a simple model to calculate how far moraine material can travel onto the glacier. The model is based on the reach angle principle. The reach angle is the angle between the origin and maximum reach of a mass movement and has a range between 3 and $45^{\circ}$ (Evans and Hungr, 1993). For debris flows, the reach angle is generally between 26 and $34^{\circ}$ (De Haas et al., 2015). These variations are mainly caused by differences in processes, but the volume of the mass wasting is also important (Dai and Lee, 2002). Taking both process and volume into account, minimum reach angles for rockfall, shallow slides and debris flows are found to be $33^{\circ}$ (with a volume of 100 $\left.1000 \mathrm{~m}^{3}\right), 23^{\circ}\left(800-2000 \mathrm{~m}^{3}\right)$ and $22^{\circ}\left(800-2000 \mathrm{~m}^{3}\right)$, respectively (Corominas et al., 2003). Reach angles decrease for values beyond these ranges and increase for smaller volumes.

The runout length $R_{\mathrm{L}}(\mathrm{m})$ from the lower moraine boundary was calculated as

$R_{\mathrm{L}}=\frac{\Delta H}{\tan \left(R_{\alpha}\right)}-M_{\mathrm{w}}$,

where $\Delta H$ is the difference in elevation between the start and deposition location (m), $R_{\alpha}\left({ }^{\circ}\right)$ is the reach angle (Fig. 9a), and $M_{\mathrm{w}}$ is the planar moraine width (m). To derive the maximum runout length, it was assumed that the start location of the mass transport is at the moraine crest, though in reality they may start from anywhere inside the gullied zone (Curry et al., 2006).

As the minimum reach angles were used and since we assume the moraine crest as a starting point, the calculated runout length $R_{\mathrm{L}}$ indicates the furthest inward point on the glacier that debris can directly be transported to. Due to a decrease in mass movement velocity after the abrupt slope change on the glacier-moraine boundary, the amount of debris deposition is expected to be highest close to the moraine and will decrease rapidly with distance. To validate this estimated runout length, the actual runout length is determined by detecting depositional features such as debris flow lobes and rockfalls, and measuring their distance to the moraine edge.

\subsection{Clast analysis}

Model results were validated by performing a clast analysis, which is used to distinguish between actively transported clasts and those that are mostly affected by weathering and reworking in rapid mass movement events (Lukas et al., 2013) and passively transported by the glacier. Morainederived debris is assumed to have already been actively transported by the ice during moraine formation, when the subglacial sediment was being deformed. Therefore, it has a higher roundness than passively transported rockwallderived debris, which is expected to be more dominant in the centre of the tongue. If the lateral moraine indeed is an important source of debris, clast roundness is expected to decrease from the lateral moraine towards the glacier centre, as the influence of the lateral moraine diminishes and material transported from further upglacier becomes dominant. The clast analysis was conducted by investigating 70 individual samples of debris. For each of the locations, on average $46(\sigma=25)$ clasts were analysed. The roundness is determined based on the commonly used chart from Powers (1953), which results in a percentage of clasts for each sample that are angular or very angular (RA index). For 13 samples, the axis length of each clast was measured, allowing us to determine the so-called $C_{40}$, which is the 40th percentile ratio of short to long axes $(c / a)$ in a sample. Actively transported clasts are more likely to have low $C_{40}$ and RA values, in contrast to clasts that experienced passive transport (Lukas et al., 2013). It has to be taken into account that both the $C_{40}$ and RA indices decline downglacier (Benn and Ballantyne, 1994) and that differences in lithology result in different index values (Lukas et al., 2013). However, the latter will be of minor importance as the debris catchment is relatively small and homogeneous in lithology (Macfarlane et al., 1992).

\section{Results and discussion}

\subsection{Observed surface lowering rates}

The mean elevation change rate of the non-vegetated moraine between May 2013 and April 2018 equals $-0.31 \pm$ $0.26 \mathrm{~m}$ year $^{-1}$ (Table 3 ). Most elevation change occurs on the lower moraine, consisting of extensively reworked coalescing debris cones, at a rate of approximately $-0.41 \pm$ 0.21 mear $^{-1}$. The glacier downwasting near the debris apron occurred at a rate of $-0.60 \pm 0.45 \mathrm{~m} \mathrm{year}^{-1}$, which indicates a deposition rate of $+0.19 \mathrm{~m} \mathrm{year}^{-1}$ on the apron, assuming a similar downwasting rate below the apron. The upper gullied part on average has a surface lowering rate of $-0.16 \pm 0.26 \mathrm{~m}_{\text {year }}{ }^{-1}$. Debris remobilization on other moraines that formed during recent glaciations generally have lower elevation change rates than those observed on the gullies in this study but also peaked at approximately $-0.15 \mathrm{~m}$ year $^{-1}$ (Curry et al., 2006), with Ballantyne and Benn (1994) noting their rates between -0.01 and $-0.02 \mathrm{~m} \mathrm{year}^{-1}$ to be minimum rates. The high gully erosion rates found are indicative of rapid surface change on steep lateral moraines above downwasted glacier tongues during deglaciation and debuttressing. The vertical accuracy of the dataset is determined by calculating DEM differences for off-glacier terrain for all datasets. The total offset is $-0.05 \pm 0.84 \mathrm{~m}$ over an area of $1.6 \mathrm{~km}^{2}$. Although the offset varies from $-0.04 \pm 0.70$ to $0.12 \pm 0.66 \mathrm{~m}$ between the different time steps, it is at any time smaller than the observed surface lowering rates (Table 4). 
Table 3. Seasonal elevation change values, furthermore divided into upper and lower moraine. The zonal mean $(\mu)$ is reported, as well as the $1 \sigma$ standard deviation $(\sigma)$. Precipitation is measured at Kyanjing station in 2013 and Langshisha station in all others seasons. Elevation change values are in $\mathrm{m} \mathrm{year}^{-1}$, precipitation values in $\mathrm{mm}$ and $\mathrm{mm} \mathrm{h}^{-1}$. The significance column (sig) indicates the periods from which that specific dataset statistically differs $(p<0.05)$.

\begin{tabular}{|c|c|c|c|c|c|c|c|c|c|c|c|c|}
\hline \multirow[b]{2}{*}{ Period } & \multirow[b]{2}{*}{ Dataset (yyyy/mm) } & \multicolumn{3}{|c|}{ Entire moraine } & \multicolumn{3}{|c|}{ Gullied upper part } & \multicolumn{3}{|c|}{ Debris apron } & \multicolumn{2}{|c|}{ Precipitation } \\
\hline & & $\mu$ & $\sigma$ & Sig & $\mu$ & $\sigma$ & Sig & $\mu$ & $\sigma$ & Sig & Cumulative & $\begin{array}{r}\text { Mean } \\
\text { intensity }\end{array}$ \\
\hline 1 & 2013/05-2013/10 (wet) & -0.39 & 0.79 & all & -0.28 & 0.77 & all & -0.41 & 0.83 & $2,4-6$ & 697 & 0.90 \\
\hline 2 & 2015/10-2016/04 (dry) & -0.17 & 0.44 & all & -0.07 & 0.43 & all & -0.21 & 0.44 & all & 145 & 0.62 \\
\hline 3 & 2016/04-2016/10 (wet) & -0.34 & 0.57 & all & -0.14 & 0.55 & all & -0.41 & 0.59 & $2,5-6$ & 584 & 0.58 \\
\hline 4 & 2016/10-2017/04 (dry) & -0.36 & 0.37 & all & -0.24 & 0.37 & all & -0.41 & 0.36 & $1-2,5-6$ & 172 & 0.84 \\
\hline 5 & 2017/04-2017/10 (wet) & -0.52 & 0.84 & all & -0.19 & 0.82 & all & -0.60 & 0.82 & all & 541 & 0.58 \\
\hline 6 & 2017/10-2018/04 (dry) & -0.22 & 0.98 & all & -0.12 & 0.98 & all & -0.25 & 1.00 & all & 117 & 0.50 \\
\hline 7 & 2013/05-2018/04 (total) & -0.31 & 0.26 & all & -0.16 & 0.26 & all & -0.41 & 0.21 & $2,5-6$ & 2257 & 0.67 \\
\hline
\end{tabular}

Table 4. Off-glacier elevation differences on stable terrain. These differences can be seen as the vertical accuracy of that specific dataset. Values are in metres.

\begin{tabular}{lrc}
\hline Dataset (yyyy/mm) & $\mu$ & $\sigma$ \\
\hline $2013 / 05-2013 / 10$ (wet) & -0.04 & 0.44 \\
$2015 / 10-2016 / 04$ (dry) & -0.03 & 0.74 \\
$2016 / 04-2016 / 10$ (wet) & 0.12 & 0.66 \\
$2016 / 10-2017 / 04$ (dry) & -0.02 & 0.69 \\
$2017 / 04-2017 / 10$ (wet) & -0.04 & 0.70 \\
$2017 / 10-2018 / 04$ (dry) & 0.08 & 0.93 \\
$2013 / 05-2018 / 04$ (total) & -0.05 & 0.84 \\
\hline
\end{tabular}

\subsection{Mass transport mechanisms and processes}

Our data enable us to differentiate between different transport mechanisms, which can be divided into three main categories: erosion due to running water (entrainment and debris flows), larger mass movements (slumps and rockfall) and slower downslope processes (for example, slow slumping). Despite the stability of inter-gully arêtes on the upper moraine, the gullied topography indicates the importance of flow erosion processes. Debris flows and sediment loaded streams originate here mostly in the wet season, when there is frequent rainfall, often with high intensity (Table 3). Relatively high rates of surface lowering can be found just below the gullies, which might be related to the presence of easily erodible surface wash deposits (Fig. 6a). The fact that these higher rates can be found below more intensely gullied upper sections supports this. Another possibility is that these higher rates are caused by a steep scarp of fresh-looking till which commonly forms at the very base of the eroding till cliff. This scarp may be caused by the separation of the debris apron from the gullied upper section as a result of sub-apron glacial downwasting. However, no such sharp step is visible on the orthophotos, keeping the exact origin unclear.
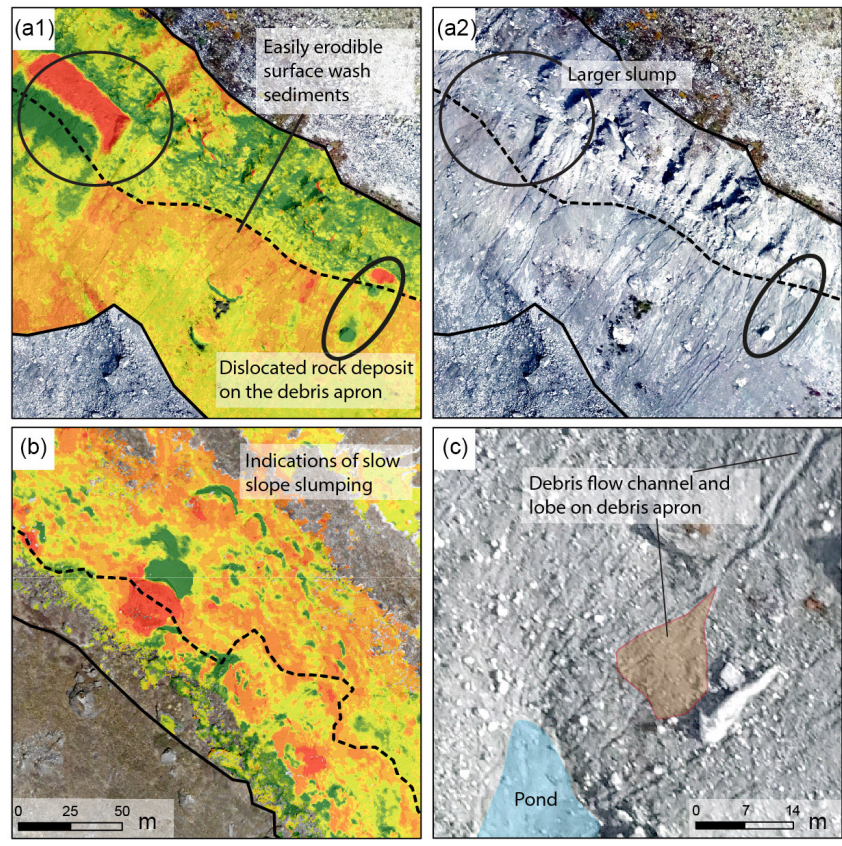

Elevation changerate $\left(\mathrm{m} \mathrm{yr}^{-1}\right)$

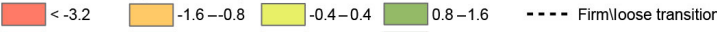

$-3.2--1.6 \square-0.8--0.4$

Figure 6. Different types or mass transport processes. Fast mass movements as slumps and rockfall occur on the moraine $(\mathbf{a 1}, \mathbf{a 2})$ as well as water-driven movement as water flow and debris flows (c). Furthermore, the slopes are slumping down slowly (b), which is clearly visible by the alternation of positive (rocks moving in) and negative (rocks moving out) elevation change values. See Fig. 2 for location.

Further down, the debris apron the slope decreases and depositional features are observed, mostly related to debris flows, as distinct levees along a central flowpath and lobelike features (Fig. 6c). Frequently observed grain diameters of $>40 \mathrm{~cm}$ on the debris apron furthermore indicate the importance of debris flows over water flows (Iverson, 1997), as 
debris flows, in contrast to water alone, are able to transport boulders of such a dimension. Nonetheless, many smaller channels show the importance of water flows for further reworking the sediment. Together with debris flows that cover the debris apron, water flow reworks the debris and transports material onto the glacier. However, due to the large elevation loss on the near moraine glacier, it is likely that there is net deposition on the debris aprons, and only a limited amount of debris is transported further onto the glacier. This is in line with the matching gully erosion rates $\left(-0.16\right.$ m year $\left.^{-1}\right)$ and approximate debris apron deposition rates $\left(+0.19 \mathrm{~m} \mathrm{year}^{-1}\right)$. The steep gullied upper slopes are also susceptible to larger mass movements, such as the occurrence of slumps and rockfalls. These processes are enhanced by oversteepening of the slope and cause locally high ( $>2 \mathrm{~m}$ ) erosion rates (Fig. 6a1). One large slump event was captured in our data (Fig. 6a1a2), deposited mostly on the debris apron, where its loose material is susceptible to continued reworking. The debris apron of the moraine is partly eroded by water flow but also moves downslope as a whole as the glacier ice below melts (Fig. 6b). There is a horizontal displacement towards the glacier of $0.93 \mathrm{~m} \mathrm{year}^{-1}$, with a 90th percentile of $2.01 \mathrm{~m} \mathrm{year}^{-1}$. This is in the range of movement by solifluction and that of rock glaciers (Matsuoka, 2001; Frauenfelder et al., 2005). Despite the fact that the local climate would favour solifluction (Gruber et al., 2017), it is unlikely to be the main transporting mechanism as velocities speed up in summer. The lateral displacement is also higher than those typically related to creep of unfrozen debris (Kirkby, 1967); thus, it is most likely caused by slow slumping of the debris apron. Although its contribution to surface lowering is unclear, this process does result in a steady debris supply to the glacier.

\subsection{Temporal patterns in surface lowering}

Moraine surface lowering occurs throughout the year, and a significant difference was observed between the wet $\left(-0.39 \pm 0.74\right.$ m year $\left.^{-1}\right)$ and dry $\left(-0.23 \pm 0.68\right.$ m year $\left.^{-1}\right)$ seasons. Elevation change rates ranged from $-0.34 \pm 0.57$ to $-0.52 \pm 0.84$ m year $^{-1}$ in the wet season and $-0.17 \pm 0.44$ to $-0.36 \pm 0.37 \mathrm{myear}^{-1}$ in the dry season. This difference is caused by heavier precipitation during the summer months (540-700 mm) compared to the winter months (117$145 \mathrm{~mm})$ in addition to higher glacial melt rates of $-0.76 \pm$ 0.73 m year $^{-1}$ and $-0.57 \pm 0.45$ mear $^{-1}$, respectively. On the upper gullied moraine, erosion rates were highly variable between the dry and wet seasons $(-0.07 \pm 0.43$ to $-0.28 \pm$ $0.77 \mathrm{~m}$ year $^{-1}$ ) but generally lower than rates on the debris apron of the moraine $\left(-0.25 \pm 1.0\right.$ to $\left.-0.60 \pm 0.82 \mathrm{~m} \mathrm{year}^{-1}\right)$. The remarkably high elevation loss on the debris apron during the wet season is mostly linked due to high glacier melt rates in the summer season. In addition, more active mass transport processes were observed in the wet seasons, contributing to the higher surface lowering rates. This also in- dicates the importance of water-driven erosion and slumping (Table 3).

The upper gullied moraine experiences less change throughout the dry season, but its high seasonal differences indicate its sensitivity to precipitation changes, which affect debris flow probabilities. During the dry season from 2016 to 2017 , when surface lowering of the gullied part was especially high, both the total precipitation as well as the intensity were considerably higher. An increase of debris-flow-related landforms after the wet season co-occurs with the larger negative elevation change that was observed on the gullied upper part. Larger slumps and rockfall from this section were not limited to a single season, as they are mostly triggered by a single rainfall event rather than by continuous wetting. Surface wash deposits below the gullies can also be seen throughout the wet and dry seasons, as is the case for slow slumping of the debris apron. Nonetheless, the rate of movement was much faster during the wet summer season, as a larger loading and a decrease of shear strength may cause the moraine to slump faster as a result of buried ice melt (Cai and Ugai, 2004). Although the exact nature of this process is yet unclear and needs further investigation, it is clear that this does contribute substantially to the downslope movement of moraine debris.

Beyond precipitation, freeze-thaw cycles could also play a role in driving erosion, with erosion increasing as moraine slopes warm up seasonally after the dry winter season and diurnally through the rest of the year.

\subsection{Towards a conceptual lateral moraine mass transport model}

The steep intensely gullied upper part of the moraine had lower elevation change rates $\left(-0.16 \mathrm{~m}\right.$ year $\left.^{-1}\right)$ than the lower debris apron part $\left(-0.41 \mathrm{~m} \mathrm{year}^{-1}\right)$ (Fig. 6). However, with a glacial melt rate of $-0.60 \pm 0.45 \mathrm{~m} \mathrm{year}^{-1}$ there is net deposition on the debris apron. This is in line with other studies that indicate that post-deglaciation the steep upper slopes get rapidly deprived of their loose sediment (Ballantyne, 2013; Curry et al., 2006). This would suggest higher erosion rates on the upper moraine part in the past, and this hypothesis is supported by the large amount of deposited material below. Currently, erosion still occurs in the gullies, albeit at a lower rate, and gully surface wash deposition just below the gullies fills the gaps between the larger boulders and decreases the surface roughness locally (Fig. 5c). These finer-grained deposits are susceptible to reworking by water flow (van Rijn, 1984).

Debris flows originating in the upper gullies both deposit and entrain material on the coalescing debris cones that form the lower part of the moraine. In addition, mass transport on this section of the moraine is caused by a slower slumping process in the wet season, which moves down the moraine as a block. During the wet summer, when surface displacement rates are on average $>1 \mathrm{~m}_{\text {year }}{ }^{-1}$, higher velocities co- 


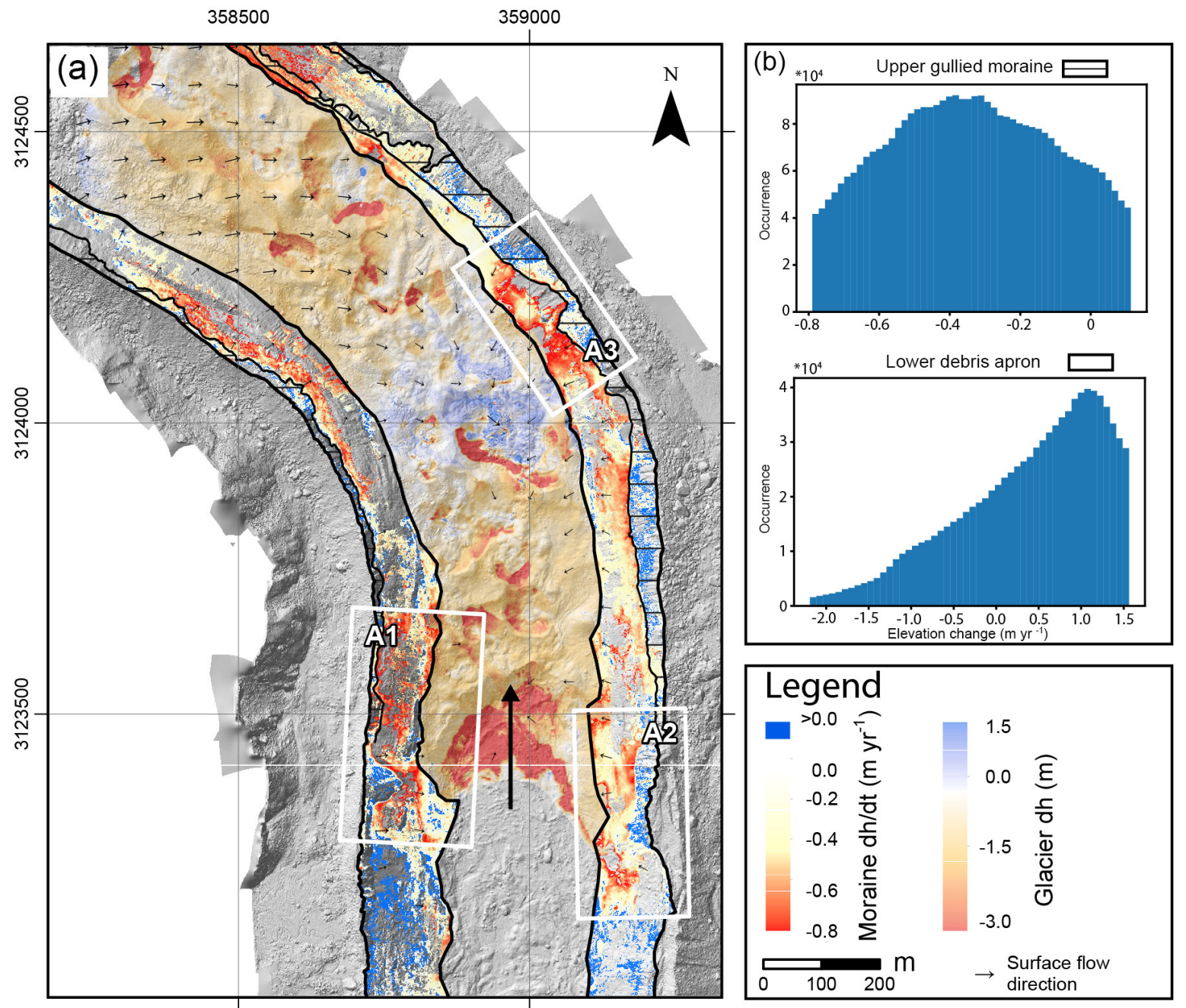

Figure 7. Downwasting of the glacier surface between May and October 2013 (Immerzeel et al., 2014a) and surface flow direction (Kraaijenbrink et al., 2016) compared to elevation change on the moraines (a). Insets (A1), (A2) and (A3) show hotspots of surface lowering. Small black arrows show surface motion, either by active debris transport or passive transport imposed by the glacier velocity. The arrow size indicates exaggerated intensity of velocity, as velocities on the moraines (mean: $0.89 \mathrm{~m}_{\text {year }}{ }^{-1}$ ) are far smaller than on the upper glacier (mean: $\sim 6$ m year $^{-1}$ ). The long black arrow shows retreat of the terminus between 2013 and $2018(\sim 150 \mathrm{~m})$. Blank areas are either outside the study area, vegetated or outside the 10-90th percentile range. Panel (b) shows the histograms of the elevation change on the upper gullied section and lower debris apron over the entire studied period (2018-2013).

incide with a more negative elevation change, possibly related to the melt of ice underneath (Fig. 8). In the dry winter season, displacement rates are lower $\left(<1 \mathrm{~m} \mathrm{year}^{-1}\right)$ and do not show a correlation with elevation change, indicating a smaller importance of slow slumping processes. This is remarkable considering the still relatively high melt rates $\left(-0.57 \pm 0.45 \mathrm{~m}\right.$ year $\left.^{-1}\right)$. The slumping might be enhanced in close proximity of areas of high glacier ice mass loss, as the ice thins vertically but also recedes laterally (Fig. 7). These slump deposits may be identified on the moving glacier as positive surface elevation change due to the dispersal of the deposited slump sediments (Fig. 7b). The gullied upper moraine did not show any horizontal displacement over both seasons, which indicates the absence of sub-moraine ice in these parts and the absence of a slumping process. As these displacements can be linked directly to a slumping process, they can easily be used to indicate areas of active mass transport on lateral moraines.

It is difficult to quantify the importance of fast processes such as debris flows, rockfall of individual large boulders and landslides on the moraine. However, the intensely gullied upper part prevents large flows from occurring. Though rockfalls and a single slump are observed, they are infrequent and occur at a small scale (Fig. 6). As a result, large infrequent events are of minor importance for the lateral morainederived sediment budget on this glacier. 

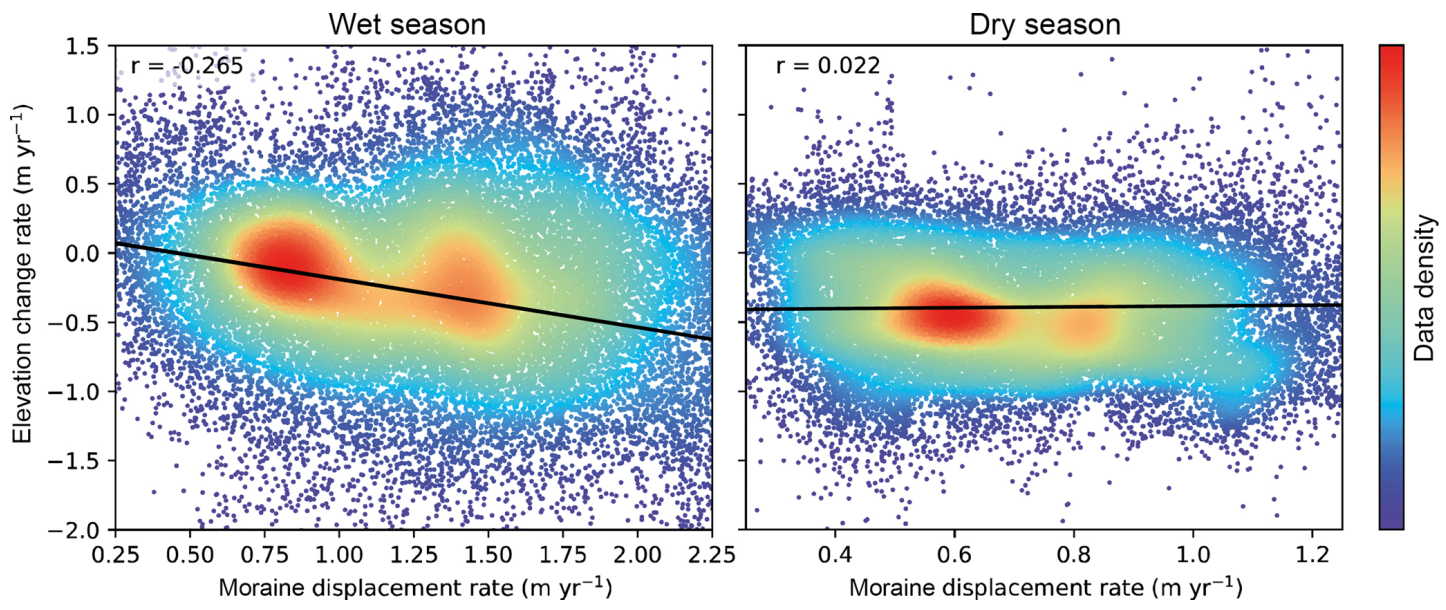

Figure 8. Relation between elevation change and moraine velocity in the wet and dry seasons. In the wet season, high velocities occur with higher surface lowering rates. Debris apron displacement is likely caused by a slumping movement due to sub-apron ice melt. No such relation exists in the dry season.

The importance of frost action for supplying detachable sediments can also not be directly derived from the DEM differencing. However, with surface temperatures well below freezing level for a long time in winter, as evidenced by field measurements, the formation of ice crystals is likely. These may detach sediments that can easily be removed afterwards. No debris flows or landslides were originated on this part; hence, it is most likely that mass transport on the lower part was triggered by water and debris flows that originated in the upper gullies. The coalescing debris cones that make up the lower part of the lateral moraine along this glacier are constantly reworked, as debris flows, water flow and slow slumping transport material to the glacier. However, net deposition takes place from the gullies above, in contradiction to what the elevation change rates suggest. The continuous glacial melt also constantly increases the sediment accommodation space, resulting in less debris to reach the glacier surface.

\subsection{Debris distribution onto the glacier}

The main processes (debris flow, shallow slides, rockfall) described above were included in the model to calculate onglacier debris deposition.

Using a specific reach angle for each process, the maximum runout length on the glacier is $39 \mathrm{~m}$ for rockfall, $111 \mathrm{~m}$ for debris flow and $122 \mathrm{~m}$ for shallow slides (Fig. 9b). The runout length is not equal along the glacier, as a result of differences in moraine elevation and the hummocky glacier surface (Fig. 9c). The observed runout length is manually derived from the imagery and has a maximum of $51 \mathrm{~m}$, which suggests rockfall as the most important process, closest to this value. As rockfalls were not observed to be the most important process on the moraine, this difference also indicates that debris flows and small slumps possibly occurred with smaller runout lengths than modelled. There are two possi- ble explanations for this. First, many mass movements might have a smaller volume than the $800-2000 \mathrm{~m}^{3}$ range used in the calculation, which reduces the runout length (Corominas et al., 2003; Rickenmann, 2005). Second, the rough surface on the glacier obstructs the runout path and decreases runout length substantially (Corominas et al., 2003; Miles et al., 2017b). Using a smaller volume $\left(<800 \mathrm{~m}^{3}\right)$ and an obstructed path, the reach angle of debris flows and shallow slides decreases to $30^{\circ}$, which results in a maximum runout length of $56 \mathrm{~m}$, much closer to the observed length of $51 \mathrm{~m}$ (Fig. 9b). Nonetheless, both the calculated and measured runout lengths indicate that debris from the moraine cannot directly reach the centre of the glaciated surface, which is approximately $200 \mathrm{~m}$ from the moraine. Rough calculations of required reach angles for moraine-derived debris to reach the centreline on other glaciers in the catchment, based on the mean moraine prominence (Miles et al., 2016), show that this is likely true there as well. For the largest glacier, Langtang, the reach angle becomes $6^{\circ}$, while for the second largest, Langshisha, it is $18^{\circ}$. Due to differences in valley shape and moraine size, very different rates of relative coverage by moraine-derived debris are however possible. Due to an increasing elevation range between the moraine crest and glacier tongue, the runout length has increased over time. The debris currently found at the glacier's centreline has either moved there by secondary processes such as glacier movement and on-glacier sliding, or originated from other sources, e.g. rockwalls (Benn and Owen, 2002) or basal debris, (re-)emerging at the glacier surface towards the tongue (Boulton, 1978; Wirbel et al., 2018). This result also indicates that the proportion of moraine-derived supraglacial debris increases as the glacier downwastes. The formation of a fully lateral moraine-derived debris cover is more likely in the case of upstream medial moraine formation by confluencing glaciers, from which secondary dispersal mecha- 

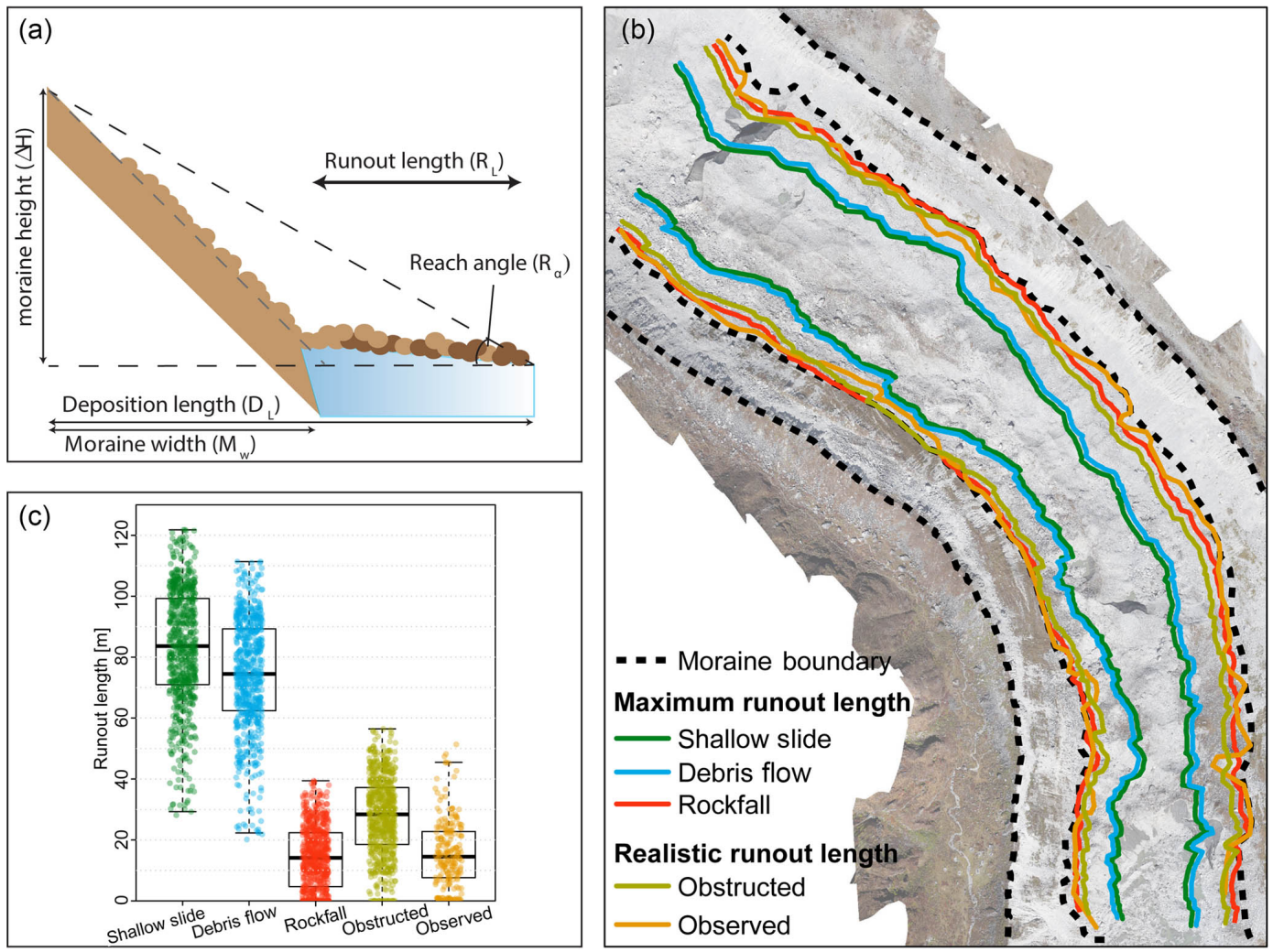

Figure 9. Conceptual diagram of model approach (a), the modelled runout lengths (b) and the modelled variability in runout lengths (c).

nisms may form a supraglacial debris cover (Kirkbride and Deline, 2013). Furthermore, advancing glaciers will have little moraine-derived input due to a lack of extensive lateral moraine slopes.

\subsection{Clast analysis}

The locations of the clast samples are shown in Fig. 10. The $C_{40}$ index is relatively low ( 0.2 to 0.48$)$, while the rounded and very rounded fractions of the investigated sample are less than $6 \%$ on average, indicative of angular clasts. Looking at the angular and very angular fractions, the RA index provides a stronger indication of transport processes (Fig. 10). The RA index on the moraine is on average just above $30 \%$, suggesting a dominance in more rounded samples. This is due to their previous transport path along the glacier bed before they were deposited along the moraine. Values are decreasing downglacier, corresponding to findings in Benn and Ballantyne (1994), indicating that englacially transported and moraine-derived debris becomes dominant. Higher RA indices on the moraine are found only where the moraine is still connected to the rockwall (Fig. 10). Clast samples in the centre of the glacier have a much higher RA index, $>50 \%$, as they have been dominantly sourced directly from rockwalls further upglacier and less frequently emerged from englacial pathways. Clast samples from between the moraine and the modelled runout length have an RA index higher than $50 \%$, closer to the RA index of the samples in the centre of the glacier. This may indicate that the modelled runout length is an upper maximum and debris from the moraines rarely reaches this far, which is in line with the observed runout length being shorter and the limited debris supply due to deposition on the debris apron.

\subsection{Consequences for debris thickness, terminus retreat and glacier downwasting}

Debris-covered tongues are schematized with a convexconcave upglacier thickness pattern, causing lower tongues to be covered in thick debris that causes debris-covered tongues to stagnate (Anderson et al., 2018; Watson et al., 2016; Kirkbride, 2000; Kirkbride and Deline, 2013). This can be explained with debris accumulating continuously at the snout at higher rates than it can be evacuated (Fig. 11a2). Moraine-derived debris can not be directly deposited over the complete width of the tongue (Fig. 11a1), although secondary processes may be capable to further distribute it across the glacier. However, to get a first-order estimate of its potential relative contribution to the thick cover expected on the snout, surface lowering rates from the moraines were compared to the overall debris thickness of the glacier. These net rates of $-0.16 \mathrm{~m} \mathrm{year}^{-1}$ on the gullied upper part and 


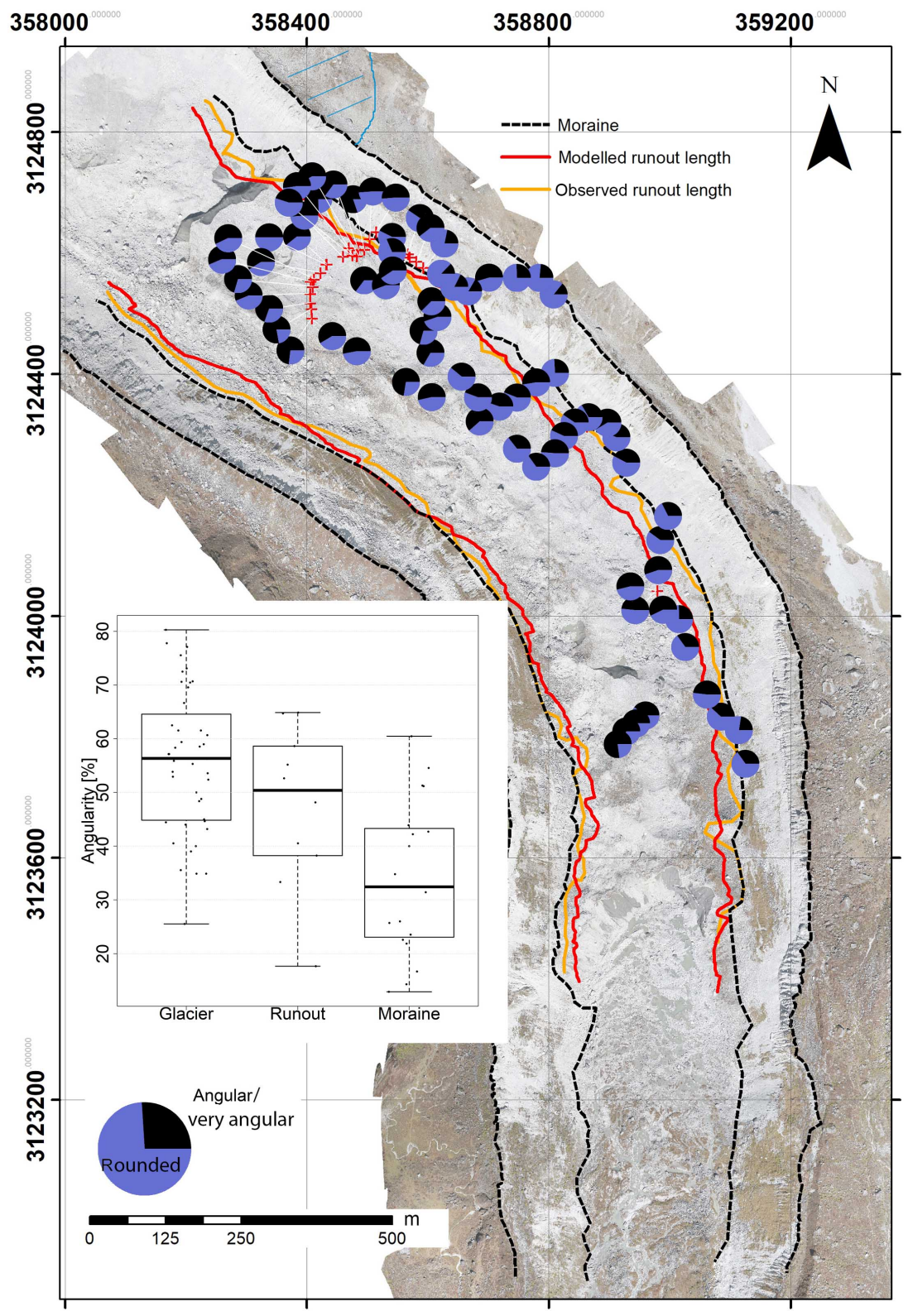

Figure 10. Angularity samples taken on the glacier surface; observed and modelled runout lengths are also shown. The inset shows angularity values for samples beyond the modelled runout length ("glacier"), between the runout length and the base of the moraine ("runout") and on the moraine ("moraine"). In the top right corner, marked in blue, the glacier is still connected to rockwalls by way of avalanching.

+0.19 m year $^{-1}$ on the debris apron suggest that no debris reaches the glacier surface, but only a relocation of moraine material takes place. However, we do see depositional features beyond the current debris apron on the glacier. In addition, one could argue that the glacial melt rates underneath the debris apron are slightly lower than those on the glacier due to the thick debris layer on top (Schomacker, 2008), which would decrease the net deposition rate on the apron and would at maximum result in no net deposition or erosion at the debris apron. This suggests that the maximum debris supply to the glacier is only related to the gully erosion rate of $-0.16 \mathrm{~m}_{\text {year }}{ }^{-1}$, which occurs over an area of $0.095 \mathrm{~km}^{2}$. If it is assumed that this amount of debris is distributed equally over the entire glacier surface within the UAV domain $\left(0.33 \mathrm{~km}^{2}\right)$, this results in an annual increase in debris thickness of $0.05 \mathrm{~m}$, although this is unlikely given the observed runout lengths. If the debris is only deposited within the area constrained by the maximum runout distance $\left(0.19 \mathrm{~km}^{2}\right)$, this implies an annual increase in debris thickness of $0.08 \mathrm{~m}$. Observed debris thickness for this glacier is in the range of $0.11-2.3 \mathrm{~m}(\mu=0.84 \mathrm{~m})$ (McCarthy et al., 2017) and 0.4-1.6 m closer to the moraine (Steiner 


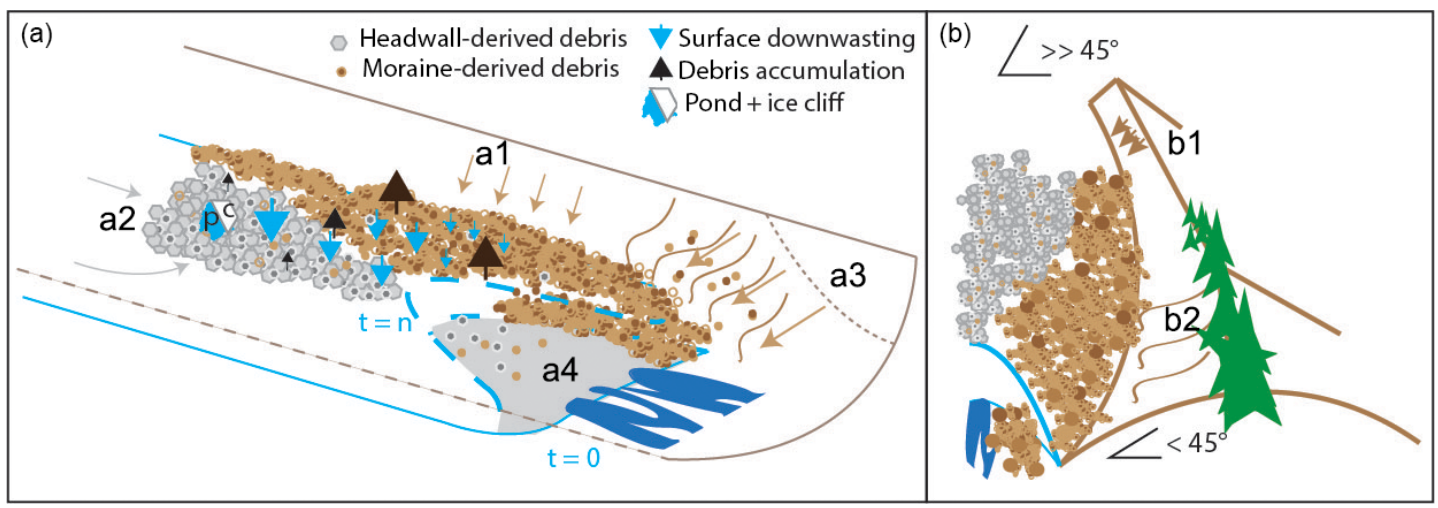

Figure 11. Dominant processes at lateral moraines and consequences for the glacier terminus of a debris-covered glacier. Mass transport from lateral moraines (a1) as well as debris transport from head walls and englacial transport (a2) are shown. Slumping as a consequence of debuttressing at the terminus (a3) brings more material into the glacier forefield (a4), as the tongue retreats in time $(t)$. As a consequence, the moraine crest slumps (b2) and the moraine becomes shallower compared to upper parts where transport is mainly to rockfall and debris flows (b1).

et al., 2018) measured around the on-glacier weather station. Furthermore, on the lower part of the Baltoro Glacier in the Karakoram, similar debris accumulation rates have been found, ranging between 0.05 and $0.30 \mathrm{~m}_{\text {year }}{ }^{-1}$, suggesting that debris-covered tongues get buried rapidly (Gibson et al., 2017b).

The clear concave arcuate terminus appearance of retreating debris-covered glaciers (DCGs) as opposed to the generally convex terminus of clean glaciers however does suggest extensive moraine sediment supply, along with internal ablation due to drainage conduits. As the tongue retreats, the debuttressing of the glacier causes the moraine to slump and fill the space available with moraine material (Fig. 11a3 and b2), which might cause the higher debris supply here. At Lirung Glacier, the terminus retreated at a rate of $30 \mathrm{~m} \mathrm{year}^{-1}$ at the centreline and much slower at the margins, as here the moraine-derived debris quickly covered the ice, resulting in the moraine crest to slump and become shallower (Fig. 11b2), and melt rates to decrease.

It is also remarkable that the near-moraine glacier downwasting rate $\left(-0.6 \mathrm{~m} \mathrm{year}^{-1}\right)$ is much lower than previously found downwasting rates over the entire glacier $(<-1.3$ and -2.18 mear $^{-1}$; Nuimura et al., 2017; Immerzeel et al., 2014a). This indicates a possibly thicker debris cover near the moraines suppressing downwasting rates, which is also in line with the lack of ponds and ice cliffs close to the moraine (Immerzeel et al., 2014a) and supports the debris supply rates presented in this paper. Considering these processes, our results indicate that lateral moraine mass transport can play an important role in debris supply to the margins of a downwasted glacier tongue with steep lateral moraines, where it offsets the downwasting of the ice with deposition of debris. As the glacier downwastes, more moraine surface is susceptible to erosion, while more space becomes available for debris apron formation, continuously inhibiting debris to reach the glacier surface. The lower the downwasting rate, the higher the possible surplus of debris that can possibly move beyond the apron and closer to the centre of the tongue, resulting in a thickening debris cover and making it a negative feedback effect. This is important to take into account in energy balance models (Carenzo et al., 2016; Rowan et al., 2015), which often use a uniform debris cover derived solely from rockwalls and do not take deposition and remobilization of lateral moraine debris into account. Lateral moraine debris supply is also found to be important for the form of terminus retreat.

\section{Conclusion}

In this study, a time series of 5 years of UAV data is used to investigate the importance of lateral moraine mass transport to a debris-covered tongue and the following key conclusions are drawn:

- The surface lowering on the lateral moraines is high at an average rate of $0.31 \mathrm{~m} \mathrm{year}^{-1}$, also attributed partially to the melt of sub-moraine ice. This translates to a maximum increase of debris thickness of $0.08 \mathrm{~m} \mathrm{year}^{-1}$ in a narrow runout zone of approximately $50 \mathrm{~m}$ next to the moraine.

- As the downwasting rate decreases, this rate of thickening will likely increase, resulting in a negative feedback with increasing debris thickness and reduced melt rates. If supplied far enough upstream, this additional debris may then be redistributed on the glacier surface.

- There is a strong seasonality in lateral moraine mass transport and the rates are higher in the wet summer season, which indicates the combination of water-driven processes and glacier melt as key mechanisms. 
- The steep upper part of the moraine is intensely gullied and transports debris quickly to the depositional debris apron. Here, the more gentle slopes are reworked by water flow, debris flow entrainment and slow slumping.

- Rockfall and landslides occur occasionally and influence the vertical elevation change pattern; they are, however, of minor importance in the overall balance.

- Runout distance modelling shows that it is unlikely that these processes are responsible for the distribution of the eroded material on the glacier since the maximum distance is small $(\sim 56 \mathrm{~m})$. This is supported by the clast analysis, which shows angularity to increase rapidly from the moraine $30 \%$ being angular or very angular) towards the glacier centre (>55\% being angular or very angular), in addition to reduced melt rates near the glacier margin.

- Considering these results and revisiting our initial hypothesis, debris supply from lateral moraines alone can not explain the thick and continuous debris cover of tongues on debris-covered glaciers. While a considerable amount of debris from the moraines reaches the surface, it can only explain thickening on the margins of the tongue.

- Further research is needed that incorporates glacier dynamics and lateral drag with the moraines and its implications for possible debris transport on the glacier surface. In addition, methods to quantify rockwall erosion rates as well as subglacial erosion on debris-covered glaciers need to be developed to understand the full sediment balance of a debris-covered glacier tongue. Better estimations of sub-debris apron glacier melt would also greatly improve the debris supply estimations. Using different future scenarios of glacier recession, the longterm development of lateral moraines and their changing contribution to an increasing debris cover could also be investigated in a dedicated modelling study.

Data availability. The elevation difference datasets from which the values in this paper are derived can be found at the following DOI: https://doi.org/10.5281/zenodo.2682541 (van Woerkom and Kraaijenbrink, 2019).

Author contributions. JFS, PDAK, ESM and WWI developed the research goal. TvW, JFS and PDAK performed the primary data analysis and model development. TvW, JFS and WWI wrote the paper. PDAK and ESM helped with interpretation of results.

Competing interests. The authors declare that they have no conflict of interest.
Acknowledgements. The input from Tjalling de Haas on mass transport processes is greatly appreciated.

Financial support. This research has been supported by the European Research Council (ERC) under the European Union's Horizon 2020 research and innovation programme (grant agreement no. 676819) and by the research programme VIDI with project number 016.161.308 financed by the Netherlands Organisation for Scientific Research (NWO).

Review statement. This paper was edited by Niels Hovius and reviewed by Simon Pendleton, Martin Kirkbride, Martin Truffer, and one anonymous referee.

\section{References}

Anderson, R. S., Anderson, L. S., Armstrong, W. H., Rossi, M. W., and Crump, S. E.: Glaciation of alpine valleys: The glacier - debris-covered glacier - rock glacier continuum, Geomorphology, 311, 127-142, https://doi.org/10.1016/j.geomorph.2018.03.015, 2018.

Ballantyne, C. K.: Paraglacial Geomorphology, in: Encyclopedia of Quaternary Science: Second Edition, Pergamon, vol. 21, 553-565, https://doi.org/10.1016/B978-0-444-53643-3.00089-3, 2013.

Ballantyne, C. K. and Benn, D. I.: Paraglacial Slope Adjustment and Resedimentation Following Recent Glacier Retreat, Fabergstolsdalen, Norway, Arctic Alpine Res., 26, 255-269, https://doi.org/10.2307/1551938, 1994.

Benn, D. I. and Ballantyne, C. K.: Reconstructing the transport history of glacigenic sediments: a new approach based on the covariance of clast form indices, Sediment. Geol., 91, 215-227, https://doi.org/10.1016/0037-0738(94)90130-9, 1994.

Benn, D. I. and Owen, L. A.: Himalayan glacial sedimentary environments: A framework for reconstructing and dating the former extent of glaciers in high mountains, Quatern. Int., 97-98, 3-25, https://doi.org/10.1016/S1040-6182(02)00048-4, 2002.

Bolch, T., Kulkarni, A., Kääb, A., Huggel, C., Paul, F., Cogley, J. G., Frey, H., Kargel, J. S., Fujita, K., Scheel, M., Bajracharya, S., and Stoffel, M.: The state and fate of himalayan glaciers, Science, 336, 310-314, https://doi.org/10.1126/science.1215828, 2012.

Boulton, G. S.: Boulder shapes and grain-size distributions of debris as indicators, Sedimentology, 25, 773-799, 1978.

Brun, F., Berthier, E., Wagnon, P., Kääb, A., and Treichler, D.: A spatially resolved estimate of High Mountain Asia glacier mass balances from 2000 to 2016, Nat. Geosci., 10, 668-673, https://doi.org/10.1038/ngeo2999, 2017.

Cai, F. and Ugai, K.: Numerical Analysis of Rainfall Effects on Slope Stability, Int. J. Geomech., 4, 69-78, https://doi.org/10.1061/(ASCE)1532-3641(2004)4:2(69), 2004.

Carenzo, M., Pellicciotti, F., Mabillard, J., Reid, T., and Brock, B. W.: An enhanced temperature index model for debris-covered glaciers accounting for thickness effect, Adv. Water Resour., 94, 457-469, https://doi.org/10.1016/j.advwatres.2016.05.001, 2016. 
Corominas, J., Copons, R., Vilaplana, J. M., Altimir, J., and Amigó, J.: Integrated Landslide Susceptibility Analysis and Hazard Assessment in the Principality of Andorra, Nat. Hazards, 30, 421435, https://doi.org/10.1023/B:NHAZ.0000007094.74878.d3, 2003.

Curry, A. M., Cleasby, V., and Zukowskyj, P.: Paraglacial response of steep, sediment-mantled slopes to post-'Little Ice Age' glacier recession in the central Swiss Alps, J. Quaternary Sci., 21, 211225, https://doi.org/10.1002/jqs.954, 2006.

Dai, F. C. and Lee, C. F.: Landslide characteristics and slope instability modeling using GIS, Lantau Island, Hong Kong, Geomorphology, 42, 213-228, https://doi.org/10.1016/S0169$555 \mathrm{X}(01) 00087-3,2002$.

De Haas, T., Braat, L., Leuven, J. R., Lokhorst, I. R., and Kleinhans, M. G.: Effects of debris flow composition on runout, depositional mechanisms, and deposit morphology in laboratory experiments, J. Geophys. Res.-Earth, 120, 1949-1972, https://doi.org/10.1002/2015JF003525, 2015.

Deline, P.: Change in surface debris cover on Mont Blanc massif glaciers after the "Little Ice Age" termination, Holocene, 15, 302-309, https://doi.org/10.1191/0959683605hl809rr, 2005.

Deline, P., Gruber, S., Delaloye, R., Fischer, L., Geertsema, M., Giardino, M., Hasler, A., Kirkbride, M., Krautblatter, M., Magnin, F., McColl, S., Ravanel, L., and Schoeneich, P.: Ice Loss and Slope Stability in High-Mountain Regions, in: Snow and Ice-Related Hazards, Risks, and Disasters, Elsevier, 521-561, https://doi.org/10.1016/B978-0-12-394849-6.00015-9, 2014.

Evans, S. and Hungr, O.: The assessment of rockfall hazard at the base of talus slopes, Can. Geotech. J., 30, 620-636, https://doi.org/10.1139/t93-054, 1993.

Frauenfelder, R., Laustela, M., and Kääb, A.: Relative age dating of Alpine rockglacier surfaces, Z. Geomorphol., 49, 145-166, available at: https://www.schweizerbart.de/papers/zfg/detail/ 49/64937/Relative_age_dating_of_Alpine_rockglacier_surfaces (last access: 8 May 2019), 2005.

Gardelle, J., Berthier, E., and Arnaud, Y.: Slight mass gain of Karakoram glaciers in the early twenty-first century, Nat. Geosci., 5, 322-325, https://doi.org/10.1038/ngeo1450, 2012.

Gibson, M. J., Glasser, N. F., Quincey, D. J., Mayer, C., Rowan, A. V., and Irvine-Fynn, T. D.: Temporal variations in supraglacial debris distribution on Baltoro Glacier, Karakoram between 2001 and 2012, Geomorphology, 295, 572-585, https://doi.org/10.1016/j.geomorph.2017.08.012, 2017a.

Gibson, M. J., Glasser, N. F., Quincey, D. J., Rowan, A. V., and Irvine-Fynn, T. D.: Changes in glacier surface cover on Baltoro glacier, Karakoram, north Pakistan, 2001-2012, J. Maps, 13, 100-108, https://doi.org/10.1080/17445647.2016.1264319, $2017 b$.

Gruber, S., Fleiner, R., Guegan, E., Panday, P., Schmid, M.-O., Stumm, D., Wester, P., Zhang, Y., and Zhao, L.: Review article: Inferring permafrost and permafrost thaw in the mountains of the Hindu Kush Himalaya region, The Cryosphere, 11, 81-99, https://doi.org/10.5194/tc-11-81-2017, 2017.

Heimsath, A. M. and McGlynn, R.: Quantifying periglacial erosion in the Nepal high Himalaya, Geomorphology, 97, 5-23, https://doi.org/10.1016/j.geomorph.2007.02.046, 2008.

Herreid, S., Pellicciotti, F., Ayala, A., Chesnokova, A., Kienholz, C., Shea, J., and Shrestha, A.: Satellite observations show no net change in the percentage of supraglacial debris-covered area in northern Pakistan from 1977 to 2014, J. Glaciol., 61, 524-536, https://doi.org/10.3189/2015JoG14J227, 2015.

Immerzeel, W. W., Van Beek, L. P., and Bierkens, M. F.: Climate change will affect the asian water towers, Science, 328, 1382 1385, https://doi.org/10.1126/science.1183188, 2010.

Immerzeel, W. W., Kraaijenbrink, P. D., Shea, J. M., Shrestha, A. B., Pellicciotti, F., Bierkens, M. F., and De Jong, S. M.: Highresolution monitoring of Himalayan glacier dynamics using unmanned aerial vehicles, Remote Sens. Environ., 150, 93-103, https://doi.org/10.1016/j.rse.2014.04.025, 2014a.

Immerzeel, W. W., Petersen, L., Ragettli, S., and Pellicciotti, F.: The importance of observed gradients of air temperature and precipitation for modeling runoff from a glacierized watershed in the Nepalese Himalayas, Water Resour. Res., 50, 2212-2226, https://doi.org/10.1002/2013WR014506, 2014b.

Iverson, R. M.: The physics of debris flows, Rev. Geophys., 35, 245-296, https://doi.org/10.1029/97RG00426, 1997.

Kääb, A., Berthier, E., Nuth, C., Gardelle, J., and Arnaud, Y.: Contrasting patterns of early twenty-first-century glacier mass change in the Himalayas, Nature, 488, 495-498, https://doi.org/10.1038/nature11324, 2012.

Kirkbride, M. P.: Ice-marginal geomorphology and Holocene expansion of debris-covered Tasman Glacier, New Zealand, 211217, available at: http://hydrologie.org/redbooks/a264/iahs_264_ 0211.pdf (last access: 8 May 2019), 2000.

Kirkbride, M. P. and Deline, P.: The formation of supraglacial debris covers by primary dispersal from transverse englacial debris bands, Earth Surf. Proc. Land., 38, 1779-1792, https://doi.org/10.1002/esp.3416, 2013.

Kirkby, M. J.: Measurement and Theory of Soil Creep, J. Geol., 75, 359-378, https://doi.org/10.1086/627267, 1967.

Kraaijenbrink, P., Meijer, S. W., Shea, J. M., Pellicciotti, F., De Jong, S. M., and Immerzeel, W. W.: Seasonal surface velocities of a Himalayan glacier derived by automated correlation of unmanned aerial vehicle imagery, Ann. Glaciol., 57, 103-113, https://doi.org/10.3189/2016AoG71A072, 2016.

Kraaijenbrink, P. D., Bierkens, M. F., Lutz, A. F., and Immerzeel, W. W.: Impact of a global temperature rise of 1.5 degrees Celsius on Asia's glaciers, Nature, 549, 257-260, https://doi.org/10.1038/nature23878, 2017.

Leprince, S., Ayoub, F., Klinger, Y., and Avouac, J. P.: Co-Registration of Optically Sensed Images and Correlation (COSI-Corr): An operational methodology for ground deformation measurements, in: International Geoscience and Remote Sensing Symposium (IGARSS), 23-28 July 2007, Barcelona, Spain, 1943-1946, IEEE, https://doi.org/10.1109/IGARSS.2007.4423207, 2007.

Lucieer, A., Jong, S. M., and Turner, D.: Mapping landslide displacements using Structure from Motion (SfM) and image correlation of multi-temporal UAV photography, Prog. Phys. Geog., 38, 97-116, https://doi.org/10.1177/0309133313515293, 2014.

Lukas, S., Graf, A., Coray, S., and Schlüchter, C.: Genesis, stability and preservation potential of large lateral moraines of Alpine valley glaciers - towards a unifying theory based on Findelengletscher, Switzerland, Quaternary Sci. Rev., 38, 27-48, https://doi.org/10.1016/j.quascirev.2012.01.022, 2012.

Lukas, S., Benn, D. I., Boston, C. M., Brook, M., Coray, S., Evans, D. J., Graf, A., Kellerer-Pirklbauer, A., Kirkbride, M. P., Krabbendam, M., Lovell, H., Machiedo, M., Mills, S. C., Nye, 
K., Reinardy, B. T., Ross, F. H., and Signer, M.: Clast shape analysis and clast transport paths in glacial environments: A critical review of methods and the role of lithology, Earth-Sci. Rev., 121, 96-116, https://doi.org/10.1016/j.earscirev.2013.02.005, 2013.

Macfarlane, A. M., Hodges, K. V., and Lux, D.: A structural analysis of the Main Central Thrust zone, Langtang National Park, central Nepal Himalaya, Geol. Soc. Am. Bull., 104, 1389-1402, https://doi.org/10.1130/00167606(1992)104<1389:ASAOTM>2.3.CO;2, 1992.

Matsuoka, N.: Solifluction rates, processes and landforms: A global review, Earth-Sci. Rev., 55, 107-134, https://doi.org/10.1016/S0012-8252(01)00057-5, 2001.

McCarthy, M., Pritchard, H., Willis, I., and King, E.: Ground-penetrating radar measurements of debris thickness on Lirung Glacier, Nepal, J. Glaciol., 63, 543-555, https://doi.org/10.1017/jog.2017.18, 2017.

Mihalcea, C., Mayer, C., Diolaiuti, G., Lambrecht, A., Smiraglia, C., and Tartari, G.: Ice ablation and meteorological conditions on the debris-covered area of Baltoro glacier, Karakoram, Pakistan, Ann. Glaciol., 43, 292-300, https://doi.org/10.3189/172756406781812104, 2006.

Mihalcea, C., Brock, B. W., Diolaiuti, G., D’Agata, C., Citterio, M., Kirkbride, M. P., Cutler, M. E., and Smiraglia, C.: Using ASTER satellite and ground-based surface temperature measurements to derive supraglacial debris cover and thickness patterns on Miage Glacier (Mont Blanc Massif, Italy), Cold Reg. Sci. Technol., 52, 341-354, https://doi.org/10.1016/j.coldregions.2007.03.004, 2008.

Miles, E. S., Pellicciotti, F., Willis, I. C., Steiner, J. F., Buri, P., and Arnold, N. S.: Refined energy-balance modelling of a supraglacial pond, Langtang Khola, Nepal, Ann. Glaciol., 57, 29-40, https://doi.org/10.3189/2016AoG71A421, 2016.

Miles, E. S., Steiner, J. F., and Brun, F.: Highly variable aerodynamic roughness length $(\mathrm{z} 0)$ for a hummocky debriscovered glacier, J. Geophys. Res.-Atmos., 122, 8447-8466, https://doi.org/10.1002/2017JD026510, 2017a.

Miles, E. S., Willis, I. C., Arnold, N. S., Steiner, J., and Pellicciotti, F.: Spatial, seasonal and interannual variability of supraglacial ponds in the Langtang Valley of Nepal, 1999-2013, J. Glaciol., 63, 88-105, https://doi.org/10.1017/jog.2016.120, 2017b.

Nicholson, L. and Benn, D. I.: Calculating ice melt beneath a debris layer using meteorological data, J. Glaciol., 52, 463-470, https://doi.org/10.3189/172756506781828584, 2006.

Nield, J. M., King, J., Wiggs, G. F., Leyland, J., Bryant, R. G., Chiverrell, R. C., Darby, S. E., Eckardt, F. D., Thomas, D. S., Vircavs, L. H., and Washington, R.: Estimating aerodynamic roughness over complex surface terrain, J. Geophys. Res.-Atmos., 118, 12948-12961, https://doi.org/10.1002/2013JD020632, 2013.

Nuimura, T., Fujita, K., and Sakai, A.: Downwasting of the debriscovered area of Lirung Glacier in Langtang Valley, Nepal Himalaya, from 1974 to 2010, Quatern. Int., 455, 93-101, https://doi.org/10.1016/j.quaint.2017.06.066, 2017.

Östrem, G.: Ice Melting under a Thin Layer of Moraine, and the Existence of Ice Cores in Moraine Ridges, Geogr. Ann., 41, 228 230, https://doi.org/10.1080/20014422.1959.11907953, 1959.

Pfeffer, W. T., Arendt, A. A., Bliss, A., Bolch, T., Cogley, J. G., Gardner, A. S., Hagen, J. O., Hock, R., Kaser, G., Kienholz, C., Miles, E. S., Moholdt, G., Mölg, N., Paul, F., Radić, V., Rastner, P., Raup, B. H., Rich, J., Sharp, M. J., Andreassen, L. M., Ba- jracharya, S., Barrand, N. E., Beedle, M. J., Berthier, E., Bhambri, R., Brown, I., Burgess, D. O., Burgess, E. W., Cawkwell, F., Chinn, T., Copland, L., Cullen, N. J., Davies, B., De Angelis, H., Fountain, A. G., Frey, H., Giffen, B. A., Glasser, N. F., Gurney, S. D., Hagg, W., Hall, D. K., Haritashya, U. K., Hartmann, G., Herreid, S., Howat, I., Jiskoot, H., Khromova, T. E., Klein, A., Kohler, J., König, M., Kriegel, D., Kutuzov, S., Lavrentiev, I., Le Bris, R., Li, X., Manley, W. F., Mayer, C., Menounos, B., Mercer, A., Mool, P., Negrete, A., Nosenko, G., Nuth, C., Osmonov, A., Pettersson, R., Racoviteanu, A., Ranzi, R., Sarikaya, M. A., Schneider, C., Sigurdsson, O., Sirguey, P., Stokes, C. R., Wheate, R., Wolken, G. J., Wu, L. Z., and Wyatt, F. R.: The randolph glacier inventory: A globally complete inventory of glaciers, J. Glaciol., 60, 537-552, https://doi.org/10.3189/2014JoG13J176, 2014.

Powers, M. C.: A New Roundness Scale for Sedimentary Particles, J. Sediment. Res., 23, 117119, https://doi.org/10.1306/D4269567-2B26-11D78648000102C1865D, 1953.

Ragettli, S., Pellicciotti, F., Immerzeel, W. W., Miles, E. S., Petersen, L., Heynen, M., Shea, J. M., Stumm, D., Joshi, S., and Shrestha, A.: Unraveling the hydrology of a Himalayan catchment through integration of high resolution in situ data and remote sensing with an advanced simulation model, Adv. Water Resour., 78, 94-111, https://doi.org/10.1016/j.advwatres.2015.01.013, 2015.

Reheis, M. J.: Source, transportation and deposition of debris on Arapaho Glacier, Front Range, Colorado, USA, J. Glaciol., 14, 407-420, 1975.

Rickenmann, D.: Runout prediction methods, in: Debris-flow Hazards and Related Phenomena, edited by: Jakob, M. and Hungr, O., chap. 13, 305-324, Springer Berlin Heidelberg, Berlin, Heidelberg, https://doi.org/10.1007/3-540-27129-5_13, 2005.

Rounce, D. R. and McKinney, D. C.: Debris thickness of glaciers in the Everest area (Nepal Himalaya) derived from satellite imagery using a nonlinear energy balance model, The Cryosphere, 8, 1317-1329, https://doi.org/10.5194/tc-8-1317-2014, 2014

Rounce, D. R., King, O., McCarthy, M., Shean, D. E., and Salerno, F.: Quantifying Debris Thickness of Debris-Covered Glaciers in the Everest Region of Nepal Through Inversion of a Subdebris Melt Model, J. Geophys. Res.-Earth, 123, 1094-1115, https://doi.org/10.1029/2017JF004395, 2018.

Rowan, A. V., Egholm, D. L., Quincey, D. J., and Glasser, N. F.: Modelling the feedbacks between mass balance, ice flow and debris transport to predict the response to climate change of debriscovered glaciers in the Himalaya, Earth Planet. Sc. Lett., 430, 427-438, https://doi.org/10.1016/j.eps1.2015.09.004, 2015.

Schauwecker, S., Rohrer, M., Huggel, C., Kulkarni, A., Ramanathan, A. L., Salzmann, N., Stoffel, M., and Brock, B.: Remotely sensed debris thickness mapping of Bara Shigri Glacier, Indian Himalaya, J. Glaciol., 61, 675-688, https://doi.org/10.3189/2015JoG14J102, 2015.

Scherler, D., Bookhagen, B., and Strecker, M. R.: Spatially variable response of Himalayan glaciers to climate change affected by debris cover, Nat. Geosci., 4, 156-159, https://doi.org/10.1038/ngeo1068, 2011.

Schomacker, A.: What controls dead-ice melting under different climate conditions? A discussion, Earth-Sci. Rev., 90, 103-113, https://doi.org/10.1016/j.earscirev.2008.08.003, 2008. 
Shukla, A., Gupta, R. P., and Arora, M. K.: Estimation of debris cover and its temporal variation using optical satellite sensor data: A case study in Chenab basin, Himalaya, J. Glaciol., 55, 444-452, https://doi.org/10.3189/002214309788816632, 2009.

Soldati, M., Corsini, A., and Pasuto, A.: Landslides and climate change in the Italian Dolomites since the Late glacial, Catena, 55, 141-161, https://doi.org/10.1016/S0341-8162(03)00113-9, 2004.

Steiner, J. F., Pellicciotti, F., Buri, P., Miles, E. S., Immerzeel, W. W., and Reid, T. D.: Modelling ice-cliff backwasting on a debris-covered glacier in the Nepalese Himalaya, J. Glaciol., 61, 889-907, https://doi.org/10.3189/2015JoG14J194, 2015.

Steiner, J. F., Litt, M., Stigter, E. E., Shea, J., Bierkens, M. F. P., and Immerzeel, W. W.: The Importance of Turbulent Fluxes in the Surface Energy Balance of a DebrisCovered Glacier in the Himalayas, Front. Earth Sci., 6, 144, https://doi.org/10.3389/feart.2018.00144, 2018.

Stokes, C. R., Popovnin, V., Aleynikov, A., Gurney, S. D., and Shahgedanova, M.: Recent glacier retreat in the Caucasus Mountains, Russia, and associated increase in supraglacial debris cover and supra-/proglacial lake development, Ann. Glaciol., 46, 195203, https://doi.org/10.3189/172756407782871468, 2007.
Thompson, S., Benn, D. I., Mertes, J., and Luckman, A.: Stagnation and mass loss on a Himalayan debris-covered glacier: Processes, patterns and rates, J. Glaciol., 62, 467-485, https://doi.org/10.1017/jog.2016.37, 2016.

van Rijn, L. C.: Sediment Transport, Part I: Bed Load Transport, J. Hydraul. Eng., 110, 1431-1456, https://doi.org/10.1061/(ASCE)0733-9429(1984)110:10(1431), 1984.

van Woerkom, T. and Kraaijenbrink, P.: Lateral moraine elevation differences along a debris covered moraine, Data set, Zenodo, https://doi.org/10.5281/zenodo.2682541, 2019.

Watanabe, T., Dali, L., and Shiraiwa, T.: Slope denudation and the supply of debris to cones in Langtang Himal, Central Nepal Himalaya, Geomorphology, 26, 185-197, https://doi.org/10.1016/S0169-555X(98)00058-0, 1998.

Watson, C. S., Quincey, D. J., Carrivick, J. L., and Smith, M. W.: The dynamics of supraglacial water storage in the Everest region, central Himalaya, Global Planet. Change, 142, 14-27, https://doi.org/10.1016/j.gloplacha.2016.04.008, 2016.

Wirbel, A., Jarosch, A. H., and Nicholson, L.: Modelling debris transport within glaciers by advection in a full-Stokes ice flow model, The Cryosphere, 12, 189-204, https://doi.org/10.5194/tc12-189-2018, 2018. 